\title{
Effect of Starvation on Tissues from the Young of Four Species, with Emphasis on the Number and Diameter of Skeletal Muscle Fibers
}

\author{
P. V. J. HEGARTY(26) AND K. O. KIM \\ Human Nutrition Research Laboratory, Department of Food Science and Nutrition, University of Minnesota, \\ St. Paul, Minnesota, USA
}

\section{Summary}

Young rats, rabbits, guinea pigs, and hamsters were decreased in body weight by $39,45,34$, and $35 \%$, respectively, by a total deprivation of food for $3,15,4$, and 4.5 days, respectively. The weight of the heart, liver, and kidneys from each of the four species (with the exception of the kidneys from the guinea pig) decreased significantly in the starved animals. After starvation in all four species, 0 to $15 \%$ of the original weight of the epididymal and perirenal fat pads remained. The effect of total starvation on the weight of skeletal muscles differed for the same muscle in different species and among the three muscles studied within a species. Starvation caused weight losses in the following muscles from the rat, rabbit, guinea pig, and hamster, respectively: soleus, $15,8,14$, and $30 \%$ plantaris, 23, 54, 41, and 24\%; biceps brachii, 27, 52, 42 , and $29 \%$. The significant loss of weight in the plantaris and biceps brachii muscles from rabbits and guinea pigs were caused by large decreases in the diameter of the fibers, with no change in the number of fibers. Soleus and plantaris muscles from hamsters decreased in weight by a reduction in fiber diameters but no change in the number of fibers; the weight of the biceps brachil decreased by a reduction in fiber number only. $A$ reduction in the number of fibers occurred in all muscles from starved rats; the diameter of the fibers was reduced in the plantaris and biceps brachii muscles. No structural damage to the fibers due to starvation was observed under the light microscope in any muscle from the four species.

\section{Speculation}

The effect of starvation on the weight of several tissues and the cellularity of skeletal muscles varied considerably among the young of four species. Some frequently studied animal models may not replicate accurately the changes observed in tissue weight and in muscle cellularity observed in severely undernourished children.

The importance of skeletal muscle as a potentially available store of protein and the extent of its reduction in children suffering from protein-energy malnutrition (PEM) has been reviewed (2, 20). Extensive muscle wasting has been reported in children with marasmus (2) and in adolescents with anorexia nervosa (5) Wasting of skeletal muscle of children due to starvation is caused by a loss of muscle fibers $(2,19)$. However, there is a lack of quantitative observations on the structure of skeletal muscles from undernourished children because of sampling and methodologic problems. For example, biopsy samples of muscles from undernourished children frequently exhibit damage to the fibers, and the biopsies do not yield enough suitable samples for direct measurement of the cross-sectional areas of the fibers (10). It is appropriate, therefore, to examine the relevance of animal models to understand the mechanisms of muscle wasting due to undernutrition. This approach is justified because animal models have been proposed for the study of PEM (13), thus allowing study of the changes in skeletal muscles during the development of PEM.

A decrease in the weight of skeletal muscles can be caused by a reduction in one or more of the following parameters: the number of fibers, and the transverse and longitudinal dimensions of fibers. There is conflicting evidence on the effect of a reduction in the rate of body weight gain on these parameters. For example, a reduction in fiber number has been reported in growing swine (22), whereas no change was observed in young rats (18). Some of the conflicting evidence in the literature is caused by the use of different methods to quantify the number and size of muscle fibers. Estimation of muscle fiber number from DNA concentrations presents difficulties in the interpretative application of these results to the multinucleated muscle fiber $(15,21)$. $\left.{ }^{15} \mathrm{~N}\right] \mathrm{Creatine}$ has been used to study muscle mass after recovery from PEM, but this method gives no indication of the extent of hypertrophy or hyperplasia in different muscles (20). A simultaneous measurement of the total number of fibers and their transverse dimension was made from a complete cross-section of the muscle in the present study. This approach is considered the most accurate to quantify changes in the cellularity of skeletal muscles.

The present study was designed to contrast the effects of a total dietary restriction on different muscles from the rat, rabbit, guinea pig, and hamster. It is acknowledged that this type of total dietary restriction is not encountered in all types of undernutrition in humans. However, guidance in the choice of experimental animals as models for PEM in infants should emerge from this type of comparative study. The weights of the heart, kidney, liver, and the epididymal and perirenal fat pads were obtained because of the significant changes in these tissues during PEM (2). Attempts were made to have the young of all four species at a similar stage of development. This is difficult to achieve (24) but desirable because of the influence of body fat content on the loss of body nitrogen by fasting humans (8).

\section{MATERIALS AND METHODS}

Young post-weanling males of the following species were studied: Sprague-Dawley rats and Syrian hamsters (ARS, Madison, WI); New Zealand white rabbits and Smooth English guinea pigs (Oak Crest Rabbitry, Edina, MN). Male animals were chosen because of their body composition. They are more susceptible than females to the damaging effects of starvation $(12,25)$. The body weights of these animals at the start of the experiment are given in Table 1. All animals were caged individually in an environmentally controlled room maintained at $22^{\circ} \mathrm{C}$ with alternate $12 \mathrm{hr}$ of light and darkness. The animals were fed the appropriate laboratory chow diets for 3 days after arrival from the suppliers. They were then assigned randomly into control and starvation groups, and the control groups were killed. All food was withdrawn from the animals that formed the starvation group; tap water was available ad libitum. A preliminary trial involving 
four or five animals from each species indicated that the decrease in body weights reported in Table 1 produced animals that were near to death from starvation. The animals were killed by ether anesthesia, and the carcasses were weighed. The gastrointestinal tract from the stomach to the rectum was removed and weighed. The weight of the entire carcass minus the weight of the gastrointestinal tract constituted the "empty body weight."

Animals from the control and starved groups were allowed to enter rigor mortis at $20^{\circ} \mathrm{C}$, which occurred at 4 to $6 \mathrm{hr}$ postmortem (11), and the tissues were then dissected. Changes in the diameter of muscle fibers do take place during the development of rigor mortis. However, this variable is less than the inaccuracies induced by fixing muscles immediately postmortem (17).

Three skeletal muscles (soleus and plantaris from the hindlimb, and the biceps brachii from the forelimb), the heart, kidney, liver, and the epididymal and perirenal fat pads were dissected from each animal. Any adhering fat and connective tissue was removed before weighing the nonadipose tissues. The skeletal muscles were fixed in buffered, neutral $10 \%$ formalin for at least one wk before determination of the number and the diameter of the fibers in each muscle by the Coulter counter method (23). This method determines simultaneously the mean diameter and the total number of fibers in a muscle. The method gives similar results to those determined by customary morphometric methods (23). Portions of the fixed muscles were also embedded in paraffin wax. Crossand longitudinal sections ( $10 \mu \mathrm{m}$ thick) were cut and stained by Masson's Trichrome (16)

\section{RESULTS AND DISCUSSION}

Total removal of food produced a body weight loss ranging from $34 \%$ in the guinea pig to $45 \%$ in the rabbit (Table 1). The more meaningful empty body weight values indicate that weight loss ranged from $31 \%$ for both the rat and the guinea pig to $39 \%$ for the rabbit. The mean number of days of total food deprivation required to achieve these body weight losses was $3,15,4$, and 4 to 5 for the rat, rabbit, guinea pig, and hamster, respectively. The weight of the heart, liver, and kidneys from each of the four species (with the exception of the kidneys from the guinea pig) decreased significantly in the starved animals. A decrease in the weight of these three tissues has been reported in children with marasmus, although the deficit is less than that seen for muscle and fat (2). However, when the weight of the heart, kidney, and liver from all four species is expressed as a percentage of body weight, then values for the heart and kidney in the starved animals are higher, and values for the liver are lower when compared to values for control animals (Table 2 ). The kidneys from the starved guinea pigs did not lose weight. The biochemical explanation of the physiologic consequences of the decrease in kidney weight in the rat, rabbit, and hamster but not in the guinea pig (Table 2) merit specific study.

The epididymal and perirenal fat pads were reduced to insignificant weights in all four species (Table 2). Fat accretion occurs in the rat and hamster primarily by hypertrophy of existing adipocytes, whereas hyperplasia is the principal factor in the guinea pig (7). Nevertheless, these cellular differences among species did not affect the ability of the animals to mobilize fat to counteract the elimination of dietary energy.

The effect of total starvation on the weight of skeletal muscles differed for the same muscle in different species and among the three muscles studied within a species (Table 3). The soleus muscle functions primarily in maintaining the posture of the animal and consists of slow-twitch, oxidative fibers (3). Starvation produced a decrease in the weight of the soleus in the hamster, but there was no effect on the weight of this muscle from the other three species. The plantaris muscle, which consists primarily of fasttwitch, oxidative glycolytic fibers (3), and the biceps brachii are involved mainly in propulsion. Both of these muscles lost a considerable amount of weight due to starvation in all four species studied. However, when muscle weight is expressed as a percentage of body weight (Table 3), there was an increase due to starvation in most muscles from the four species. For example, muscle weight as a percentage of body weight was higher for all these muscles from the starved rats, although there was a significant decrease in the weight of the plantaris and biceps brachii muscles. Values for tissue weight as a percentage of body weight in Tables 2 and 3 , were obtained by using total body weight values (Table 1). Similar trends were obtained if empty body weight values were used in the calculations.

The cellular changes involved in the loss of muscle weight are presented in Table 4. The decrease in the weight of the rat soleus muscle (Table 3) was due to a significant decrease $(P<0.01)$ in the number of fibers; there was no difference in the diameter of the fibers (Table 4). Contrast this observation with the fact that the same muscle in the starved hamster also lost a significant amount of weight $(P<0.001)$, but this loss was due to a reduction $(P<0.01)$ in the diameter of the fibers with no reduction in fiber number. Starvation produced no significant weight changes in the soleus muscle from the rabbit and the guinea pig (Table 3 ), nor did it result in differences in the number or diameter of muscle fibers (Table 4). The plantaris muscle lost weight in starved animals from the four species. The nature of the loss varied from a reduction in both fiber number and fiber diameter in the rat to a reduction in fiber diameter only in the rabbit, guinea pig, and

Table 1. Body weight ( $\mathrm{g}$ ) of control and starved animals ${ }^{1}$

\begin{tabular}{|c|c|c|c|c|}
\hline Treatment & Rat & Rabbit & Guinea pig & Hamster \\
\hline $\begin{array}{l}\text { Total body weig } \\
\text { Control }\end{array}$ & $68.0 \pm 1.6^{2}(12)^{3}$ & $1402.0 \pm \underset{4}{51.8(4)}$ & $208.2 \pm 10.0(9)$ & $69.2 \pm 1.8(11)$ \\
\hline $\begin{array}{l}\text { Starved } \\
\text { \% weight loss }\end{array}$ & $\begin{array}{l}41.6 \pm 0.6(12) \\
39 \%\end{array}$ & $\begin{array}{r}765.3 \\
45 \%\end{array}$ & $\begin{array}{r}137.3 \pm 5.1(9) \\
34 \%\end{array}$ & $\begin{array}{l}45.0 \pm 0.6(11) \\
35 \%\end{array}$ \\
\hline $\begin{array}{l}\text { Empty body wei } \\
\text { Control }\end{array}$ & $53.4 \pm 1.6(12)$ & $1094.4 \pm 21.7(4)$ & $165.2 \pm \underset{4}{8.0(9)}$ & $61.1 \pm 1.6(11)$ \\
\hline Starved & $36.7 \pm 0.5(12)$ & $665.6 \pm 12.6(4)$ & $114.2 \pm 4.1(9)$ & $41.0 \pm 0.5(11)$ \\
\hline$\%$ weight loss & $31 \%$ & $39 \%$ & $31 \%$ & $33 \%$ \\
\hline
\end{tabular}

\footnotetext{
'Significance was determined by the Students' $t$ test.

${ }^{2}$ Mean \pm S.E.

${ }^{3}$ Numbers in parentheses, number of animals in each group.

$4<0.001$
} 
Table 2. Weight of organs and fat pads and the weight of the organs as a percentage of body weight of control and starved animals

\begin{tabular}{|c|c|c|c|c|c|c|c|c|c|c|}
\hline \multirow{3}{*}{$\frac{\text { Species }}{\text { Rat }}$} & \multirow{2}{*}{\multicolumn{2}{|c|}{ Treatment }} & \multicolumn{2}{|c|}{ Heart } & \multicolumn{2}{|c|}{ Kidney } & \multicolumn{2}{|c|}{ Liver } & \multicolumn{2}{|c|}{ Fat pads (mg) } \\
\hline & & & \multirow{2}{*}{$\frac{\mathrm{mg}}{291 \pm 8^{2}}$} & \multirow{2}{*}{$\begin{array}{c}\begin{array}{c}\% \text { body } \\
\text { weight }\end{array} \\
0.43\end{array}$} & \multirow{2}{*}{$\frac{\mathrm{mg}}{397 \pm 14}$} & \multirow{2}{*}{$\begin{array}{c}\begin{array}{c}\% \text { body } \\
\text { weight }\end{array} \\
0.58\end{array}$} & \multirow{2}{*}{$\frac{g}{4.22 \pm 0.93}$} & \multirow{2}{*}{$\begin{array}{c}\begin{array}{c}\% \text { body } \\
\text { weight }\end{array} \\
6.21\end{array}$} & \multirow{2}{*}{$\frac{\text { Epididymal }}{77 \pm 8}$} & \multirow{2}{*}{$\frac{\text { Perirenal }}{40 \pm 7}$} \\
\hline & Control & $(8)^{\prime}$ & & & & & & & & \\
\hline & $\begin{array}{l}\text { Starved } \\
\% \text { loss }\end{array}$ & 12) & $\begin{array}{c}197 \\
32\end{array}$ & 0.47 & $\begin{array}{c}313 \pm 4 \\
21\end{array}$ & 0.75 & $\begin{array}{l}1.29 \pm 0.61 \\
69\end{array}$ & 3.10 & $\begin{array}{l}10 \pm 0 \\
87\end{array}$ & $\begin{array}{r}0 \\
100\end{array}$ \\
\hline \multirow[t]{2}{*}{ Rabbit } & Control & (4) & $\underset{3}{4287} \pm 240$ & 0.31 & $\underset{3}{5902 \pm 270}$ & 0.42 & $48.9 \pm \frac{3}{3} 3.9$ & 3.49 & $\underset{3}{1772} \pm 83$ & $\begin{array}{c}3169 \pm 124 \\
3\end{array}$ \\
\hline & $\begin{array}{l}\text { Starved } \\
\% \text { loss }\end{array}$ & (4) & $\begin{array}{r}2178 \pm 80 \\
49\end{array}$ & 0.29 & $\begin{array}{c}3789 \pm 60 \\
36\end{array}$ & 0.50 & $\begin{array}{c}20.2 \\
59\end{array}$ & 2.64 & $\begin{array}{r}0 \\
100\end{array}$ & $\begin{array}{r}0 \\
100\end{array}$ \\
\hline \multirow[t]{2}{*}{ Guinea pig } & Control & (6) & $901 \pm 27$ & 0.43 & $\begin{array}{c}1263 \pm 49 \\
\text { N.S. }\end{array}$ & 0.61 & $12.27 \underset{3}{ \pm} 0.9$ & 5.89 & $\underset{3}{114} \pm 18$ & $\underset{3}{201 \pm 17}$ \\
\hline & $\begin{array}{l}\text { Starved } \\
\% \text { loss }\end{array}$ & (9) & $\begin{array}{c}671 \pm 41 \\
26\end{array}$ & 0.49 & $\begin{array}{l}1275 \pm 68 \\
+1\end{array}$ & 0.93 & $\begin{array}{c}5.99 \pm 0.3 \\
51\end{array}$ & 4.36 & $\begin{array}{r}7 \pm 1 \\
94\end{array}$ & $\begin{array}{r}0 \\
100\end{array}$ \\
\hline \multirow[t]{2}{*}{ Hamster } & Control & (6) & $\underset{3}{254} \pm 6$ & 0.37 & $\underset{3}{393} \neq 11$ & 0.57 & $4.60 \pm \underset{3}{ \pm} 0.16$ & 6.65 & $\underset{3}{429 \pm 45}$ & $\underset{3}{214 \pm 41}$ \\
\hline & $\begin{array}{l}\text { Starved } \\
\% \text { loss }\end{array}$ & (9) & $\begin{array}{c}199 \pm 3 \\
22\end{array}$ & 0.44 & $\begin{array}{c}323 \pm 5 \\
18\end{array}$ & 0.72 & $\begin{array}{c}2.09 \\
55\end{array}$ & 4.64 & $\begin{array}{l}48 \pm 3 \\
89\end{array}$ & $\begin{array}{r}0 \\
100\end{array}$ \\
\hline
\end{tabular}

'Numbers in parentheses, number of animals.

${ }^{2}$ Mean \pm S.E.

${ }^{3} P<0.001$.

${ }^{4} P<0.01$.

${ }^{5}$ N.S., not significant.

Table 3. Weight (mg) and muscle weight as a percentage of body weight of control and starved animals

\begin{tabular}{|c|c|c|c|c|c|c|c|}
\hline \multirow[b]{2}{*}{ Species } & \multirow[b]{2}{*}{ Treatment } & \multicolumn{2}{|c|}{ Soleus } & \multicolumn{2}{|c|}{ Plantaris } & \multicolumn{2}{|c|}{ Biceps brachii } \\
\hline & & Weight (mg) & $\%$ body weight & Weight (mg) & $\%$ body weight & Weight (mg) & $\%$ body weight \\
\hline \multirow[t]{2}{*}{ Rat } & Control $(6)^{\prime}$ & $\begin{array}{l}22.8 \pm 1.9^{2} \\
\text { N.S. }\end{array}$ & 0.034 & $44.9 \pm 3.1$ & 0.066 & $46.3 \pm 1.8$ & 0.068 \\
\hline & $\begin{array}{l}\text { Starved (6) } \\
\% \text { loss }\end{array}$ & $\begin{array}{l}19.5 \pm 0.8 \\
15\end{array}$ & 0.047 & $\begin{array}{l}34.7 \pm 1.1 \\
23\end{array}$ & 0.083 & $\begin{array}{l}34.0 \pm 1.3 \\
27\end{array}$ & 0.082 \\
\hline \multirow[t]{2}{*}{ Rabbit } & Control (4) & $\begin{array}{l}666 \pm 6 \\
\text { N.S. }\end{array}$ & 0.048 & $1878 \pm 72$ & 0.134 & $1322 \pm \underset{5}{4} 47$ & 0.094 \\
\hline & $\begin{array}{l}\text { Starved (3) } \\
\% \text { loss }\end{array}$ & $\begin{array}{c}615 \pm 38 \\
8\end{array}$ & 0.080 & $\begin{array}{l}856 \pm 62 \\
54\end{array}$ & 0.112 & $\begin{array}{l}634 \pm 45 \\
52\end{array}$ & 0.083 \\
\hline \multirow[t]{2}{*}{ Guinea pig } & Control (6) & $\begin{array}{l}53.0 \pm 6.2 \\
\text { N.S. }\end{array}$ & 0.026 & $127.5 \pm 14.0$ & 0.061 & $159.5 \pm \frac{5.4}{5}$ & 0.077 \\
\hline & $\begin{array}{l}\text { Starved (6) } \\
\% \text { loss }\end{array}$ & $\begin{array}{c}45.7 \pm 3.7 \\
14\end{array}$ & 0.033 & $\begin{array}{c}75.2 \pm 3.8 \\
41\end{array}$ & 0.055 & $\begin{array}{c}92.7 \pm 5.3 \\
42\end{array}$ & 0.068 \\
\hline \multirow[t]{2}{*}{ Hamster } & Control (6) & $15.2 \pm 0.3$ & 0.022 & $20.8 \underset{5}{ \pm} 0.4$ & 0.030 & $46.0 \pm \frac{5}{5} .4$ & 0.067 \\
\hline & $\begin{array}{l}\text { Starved }(6) \\
\% \text { Loss }\end{array}$ & $\begin{array}{l}10.6 \pm 0.4 \\
30\end{array}$ & 0.024 & $\begin{array}{l}15.8 \pm 0.9 \\
24\end{array}$ & 0.035 & $\begin{array}{l}32.9 \pm 1.0 \\
29\end{array}$ & 0.073 \\
\hline
\end{tabular}

' Numbers in parentheses, number of animals.

${ }^{2}$ Mean \pm S.E.

${ }^{3}$ N.S., not significant.

${ }^{4} P<0.01$.

s $P<0.001$.

hamster. Cellularity changes for the biceps brachii muscle were similar to the plantaris with the exception that in the hamster there was a decrease only in the number of fibers.

Examination of transverse and longitudinal sections of each of the muscles from the four species under the light microscope confirmed the decreased diameter of the fibers obtained by the Coulter counter method. Manual counting of all the fibers in complete cross-sections of the soleus and plantaris muscles from the rat confirmed the results from the Coulter counter that starvation causes a reduction in the number of fibers. Close agreement in the determination of the number of fibers by manually counting all the fibers and by using the Coulter counter method has been reported in our laboratory for different muscles from different species that were fed adequately (23). Starvation reduced the mean 
MUSCLE CELLULARITY AFTER STARVATION

Table 4. Muscle fiber number and diameter $(\mu m)$ in control and starved animals

\begin{tabular}{|c|c|c|c|c|c|c|c|}
\hline \multirow[b]{2}{*}{ Species } & \multirow[b]{2}{*}{ Treatment } & \multicolumn{2}{|c|}{ Soleus } & \multicolumn{2}{|c|}{ Plantaris } & \multicolumn{2}{|c|}{ Biceps brachii } \\
\hline & & No. & Diameter & No. & Diameter & No. & Diameter \\
\hline \multirow[t]{2}{*}{ Rat } & Control (6) & $3110 \pm 205^{2}$ & $\begin{array}{c}25.5 \pm 0.8 \\
\text { N.S. }\end{array}$ & $5756 \pm 314$ & $20.8 \pm 0.3$ & $8741 \pm 364$ & $\underset{5}{23.0 \pm 0.3}$ \\
\hline & Starved (6) & $2255 \pm 166$ & $24.2 \pm 0.6$ & $4193 \pm 362$ & $19.4 \pm 0.6$ & $6496 \pm 585$ & $20.0 \pm 0.6$ \\
\hline \multirow[t]{2}{*}{ Rabbit } & Control (4) & $\begin{array}{c}8964 \pm 1151 \\
\text { N.S. }^{6}\end{array}$ & $\begin{array}{c}46.3 \pm 2.4 \\
\text { N.S. }\end{array}$ & $\begin{array}{c}30300 \pm 2857 \\
\text { N.S. }\end{array}$ & $41.7 \pm 2.0$ & $\begin{array}{c}22354 \pm 1335 \\
\text { N.S. }\end{array}$ & $43.1 \pm 0.3$ \\
\hline & Starved (3) & $8918 \pm 1988$ & $50.2 \pm 1.6$ & $32892 \pm 7672$ & $25.3 \pm 2.3$ & $20878 \pm 2964$ & $26.6 \pm 1.0$ \\
\hline \multirow[t]{2}{*}{ Guinea pig } & Control (6) & $\begin{array}{c}3674 \pm 368 \\
\text { N.S. }\end{array}$ & $\begin{array}{c}23.2 \pm 0.7 \\
\text { N.S. }\end{array}$ & $\begin{array}{c}8146 \pm 721 \\
\text { N.S. }\end{array}$ & $24.4 \pm 1.6$ & $\begin{array}{c}12664 \pm 1024 \\
\text { N.S. }\end{array}$ & $\begin{array}{c}24.9 \pm 0.8 \\
5\end{array}$ \\
\hline & Starved (6) & $3667 \pm 471$ & $23.7 \pm 0.6$ & $7002 \pm 639$ & $20.2 \pm 0.4$ & $13006 \pm 1235$ & $17.6 \pm 0.5$ \\
\hline \multirow[t]{2}{*}{ Hamster } & Control (6) & $\begin{array}{c}1352 \pm 133 \\
\text { N.S. }\end{array}$ & $35.5 \pm 1.3$ & $\begin{array}{c}1531 \pm 125 \\
\text { N.S. }\end{array}$ & $32.2 \pm 0.3$ & $4900 \pm 309$ & $\begin{array}{c}30.3 \pm 0.1 \\
\text { N.S. }\end{array}$ \\
\hline & Starved (6) & $1386 \pm 130$ & $29.5 \pm 0.9$ & $1959 \pm 148$ & $27.2 \pm 0.5$ & $3694 \pm 325$ & $28.8 \pm 1.1$ \\
\hline
\end{tabular}

${ }^{1}$ Numbers in parentheses, numbers of animals in each group.

${ }^{2}$ Mean \pm S.E.

${ }^{3} P<0.01$.

${ }^{4} P<0.05$.

${ }^{5} P<0.001$

${ }^{6}$ N.S., not significant.

fiber diameter of the biceps brachii of the rat from $23.0 \mu \mathrm{m}$ and reduced the number of fibers from 8741 to 6496 . However, the same muscle in the guinea pig had a reduction in the diameter of the fibers from 24.9 to $17.6 \mu \mathrm{m}$ due to starvation; there was no difference in the number of muscle fibers (Table 4). If the method used in this study was unable to detect fibers with diameters of less than $25 \mu \mathrm{m}$, then a reduction in the number of muscle fibers in the biceps brachii from the starved guinea pig would be expected.

The fact that all muscles lose weight to varying extends during prolonged total food restriction seems to be uniform in most species. However, the mechanism of this weight loss is different among species. The rabbit, guinea pig, and hamster decrease muscle weight primarily by a decrease in fiber diameter, with no change in fiber number (Table 4). In contrast, the decrease in the rat is caused by a reduction in both the diameter and the number of muscle fibers. The cause of this species difference is not readily apparent. For example, the plantaris muscle from the rat and the guinea pig lost 23 and $41 \%$ of their original weight due to starvation (Table 3). This weight loss in the rat muscle was due to a decrease in both the number and diameter of the muscle fibers, whereas in the guinea pig only the diameter of the muscle fibers decreased. Yet, the histochemical properties of this muscle from these two species are similar (3). The loss of muscle fibers in the rat does not produce the structural changes seen in undernourished humans $(2,19)$. In fact, the appearance under the light microscope of the muscles from starved rats, and from the other three species studied seems to be normal except for the reduction in fiber size when comparisons are made with adequately fed control animals Other investigators have found no ultrastructural damage to the contractile proteins of muscles from rats undergoing dietary restrictions $(1,14)$. Layman (14), in our laboratory, observed no difference in muscle cellularity when the body weight of young rats was reduced to the same extent by either a partial or a total withdrawal of food. It is readily acknowledged that nutritional stresses in humans produce multiple metabolic and nutritional abnormalities which may cause both neuropathy and myopathy. Muscles from the rat, rabbit, guinea pig, and hamster thus may differ from human muscles in their morphologic response to prolonged severe food restrictions. These differences may explain why caloric restrictions have no effect on the mechanical properties of rat muscle (18) in contrast to the pronounced detrimental effect on muscle activity in humans (2).
Furthermore, atrophy of muscles from the young of the same species may occur by different mechanisms depending on the nutritional stress. Contrast the noninvolvement of fiber loss in the muscular atrophy induced by starvation in the rabbit (Table 4) with the very extensive loss of muscle fibers when the same species is fed a vitamin E-deficient diet $(4,6)$. It is clear, therefore, that caution must be exercised in the correlation of morphologic, and perhaps biochemical, results from skeletal muscles obtained from young experimental animals from different species undergoing prolonged starvation or other nutritional stresses. This should give rise to caution in the choice of experimental animal models to duplicate the effects of undernutrition on human skeletal muscles. However, studies of this nature should be pursued because it is not clear to what extent hypertrophy and hyperplasia contributes to the muscle repletion in infants recovering from malnutrition (20).

\section{REFERENCES AND NOTES}

1. Adibi, S. A., Krzysik, B. A., Morse, E. L., and Amin. P. M.: Oxidative energy metabolism in the skeletal muscle: biochemical and ultrastructural evidence for adaptive changes. J. Lab. Clin. Med., 83: 548 (1974).

2. Alleyne, G. A. O., Hay, R. W., Picou, D. I., Stanfield, J. P., and Whitehead, R. G.: Protein-Energy Malnutrition (Edward Arnold, Lid.. London, 1977).

3. Ariano, M. A., Armstrong. R. B., and Edgerton, V. R.: Hind limb muscle fiber populations of five mammals. J. Histochem. Cytochem., 2I: 51 (1973).

4. Chan, A. C., and Hegarty, P. V. J.: Morphological changes in skeletal muscles in vitamin E-deficient and refed rabbits. Br. J. Nutr., 38: 361 (1977)

5. Crisp, A. H.: Anorexia nervosa. "Feeding disorder," "nervous malnutrition" or "weight phobia?" World Rev. Nutr. Diet.. 12: 452 (1970).

6. Dahlin, K. J., Chan, A. C., Benson, E. S., and Hegarty, P. V. J.: Rehabilitating affect of vitamin $E$ therapy on the ultrastructural changes in skeletal muscles of vitamin E-deficient rabbits. Am. J. Clin. Nutr., 31: 94 (1978).

7. Di Girolamo, M., and Mendlinger, S.: Role of fat cell size and number in enlargement of epididymal fat pads in three species. Am. J. Physiol., 221: 859 (1971).

8. Forbes, G. B., and Drenick, E. J.: Loss of body nitrogen on fasting. Am. J. Clin. Nutr., 32: 1570 (1979).

9. Hansen-Smith, F. M., Maksud, M., and Van Horn, D. L.: Effect of dietary protein restriction or food restriction on oxygen consumption and mitochondrial distribution in cardiac and red and white skeletal muscle of rats. J. Nutr., l07: 525 (1977).

10. Hansen-Smith. F. M., Picou, D., and Golden, M. H.: Growth of muscle fibres during recovery from severe malnutrition in Jamaican infants. Br. J. Nutr., 41: 275 (1979).

11. Heffron, J. J. A., and Hegarty, P. V. J.: Evidence for a relationship between ATP hydrolysis and changes in extracellular space and fibre diameter during rigor development in skeletal muscle. Comp. Biochem. Physiol., 49A: 43 (1974).

12. Jackson. C. M.: Recovery in rats upon refeeding after prolonged suppression of 
growth by dietary deficiency of protein. Am. J. Anat., 58 : 179 (1936).

13. Kirsch, R. E., Saunders, S. J., and Brock. J. F.: Animal models and human protein-calorie malnutrition. Am. J. Clin. Nutr., 21: 1225 (1968).

14. Layman, D. K.: Biochemical and morphological changes in skeletal muscle fibers during normal growth and prolonged starvation. Ph.D. Thesis (University of Minnesota, 1978)

15. Layman, D. K., Hegarty, P. V. J., and Swan, P. B.: Comparison of morphological and biochemical parameters of growth in rat skeletal muscles. J. Anat., 130: $159(1980)$.

16. Lee, G. L.: Manual of Histologic Staining Methods. Ed. 3, p. 94 (McGraw-Hill Book Co., New York, 1968).

17. Levine. A. S., and Hegarty, P. V. J.: A re-examination of the biphasic theory of skeletal muscle growth. J. Anat.. 123: 313 (1977).

18. McCarter, R., Yu, B. P., and Radicke, D.: Effect of caloric restriction on contraction of skeletal muscle. Nutr. Rep. Int., 17: 339 (1978).

19. Montgomery, R. D.: Muscle morphology in infantile protein malnutrition. J. Clin. Pathol., 15: 511 (1962)

20. Reeds, P. J., Jackson, A. A., Picou, D.. and Poulter, N.: Muscle mass and

Copyright $(1981$ International Pediatric Research Foundation, Inc. $0031-3998 / 81 / 1502-0132 \$ 02.00 / 0$ composition in malnourished infants and children and changes seen after recovery. Pediatr. Res., 12: 613 (1978).

21. Sands, J., Dobbing. J., and Gratrix, C. A.: Cell number and cell size: organ growth and development and the control of catch-up growth in rats. Lancet. 2: 503 (1979).

22. Swatland, H. J.: Effect of growth and plane of nutrition on apparent muscle fiber numbers in the pig. Growth, 40: 285 (1976).

23. Thompson, E. H., Levine, A. S., Hegarty, P. V. J., and Allen, C. E.: An automated technique for simultaneous determinations of muscle fiber number and diameter. J. Anim. Sci., 48: 328 (1979).

24. Widdowson, E. M.: Harmony of growth. Lancet, 1 : 901 (1970)

25. Widdowson, E. M.: The response of the sexes to nutritional stress. Proc. Nutr. Soc., 35: 175 (1976).

26. Requests for reprints should be addressed to: Dr. P. V. J. Hegarty, Department of Food Science and Nutrition. University of Minnesota. St. Paul, MN 55108 (USA).

27. Received for publication January 9, 1980.

28. Accepted for publication July 15, 1980. 